Article

\title{
Conference Diplomacy: The Making of the Paris Agreement
}

\author{
Aslak Brun \\ Ministry of Climate and Environment, Government of Norway, 0030 Oslo, Norway; E-Mail: aslak.brun@mfa.no
}

Submitted: 19 April 2016 | Accepted: 20 May 2016 | Published: 8 September 2016

\begin{abstract}
The article offers an insider's account of how the Paris Agreement on climate change was reached. Focusing on participation and ambition, it describes the efforts to include a long-term temperature goal, expectations for regular ratcheting up of climate efforts, and provisions for tracking global progress. The author argues that a shift from the earlier top-down approaches to setting targets, to a bottom-up, self-determined approach has spurred participation and made it easier to reach agreement. In addition, the Paris Agreement anchors a clearer direction of travel than before. The article also discusses the negotiations of the provisions in the Agreement to drive increased national climate mitigation efforts over time. Finally, the author considers the role of conference diplomacy, particularly the need for inclusive leadership. It is argued that the French Presidency combined a transparent negotiations process with a clear sense of direction that helped achieve a comprehensive and ambitious outcome. The role of back-channel talks as part of effective conference diplomacy is also discussed.
\end{abstract}

\section{Keywords}

back-channel negotiations; climate change; cooperation; diplomacy; international negotiations; participation; UN

\section{Issue}

This article is part of the issue "Climate Governance and the Paris Agreement", edited by Jon Hovi and Tora Skodvin (University of Oslo, Norway).

(C) 2016 by the author; licensee Cogitatio (Lisbon, Portugal). This article is licensed under a Creative Commons Attribution 4.0 International License (CC BY).

\section{Introduction}

In the 25 years of UN climate change negotiations we have known that we can address global warming effectively only if all countries with significant greenhouse gas emissions participate in a collective effort. Nevertheless, until Paris, all such attempts had been inadequate.

The challenge in Paris was twofold: To ensure universal participation in a climate change agreement and to enhance climate efforts significantly (if not presently, then at least over time). An effective agreement would need to enhance both participation and ambition.

Previous climate agreements have failed to deliver on both counts. The United Nations Framework Convention on Climate Change (UNFCCC) from 1992 is universal but includes no quantitative emissions limitation targets. The Kyoto Protocol (1997) includes jointly determined and legally binding targets, but only for industrialized countries. The Copenhagen Accord (2009) entails self-determined and nonbinding targets, but lacks a mechanism to assess the overall adequacy of efforts or to ratchet up efforts.

There has therefore been an inherent contradiction between participation and ambition in the climate change negotiations.

The Paris Agreement meets the two criteria better than all previous attempts do. The Conference President, Laurent Fabius, the French Foreign Minister at the time of the Paris Conference, has characterized it as 'the most balanced, comprehensive and ambitious result that we could hope to achieve' (UNFCCC, 2016a).

It is an agreement with universal participation. ${ }^{1}$ The Paris Agreement is legally binding; all parties have obligations and rights. The core of the commitment is that all parties that join the Agreement will be legally bound to regularly prepare, update, and report on national mitigation targets and other contributions. The Agree-

\footnotetext{
1 Only one party, Nicaragua, objected to the adoption of the Paris Agreement on 12 December 2015.
} 
ment is durable and dynamic and works to progressively strengthen the global effort. All parties commit to pursue domestic mitigation measures with the aim of meeting their targets. Unlike commitments under the Kyoto Protocol, however, parties' reduction or limitation targets in the Paris Agreement are not legally binding.

I will discuss the provisions in the Paris Agreement to create conditions for an international regime that promotes the evolution of voluntary, cooperative behaviour in the absence of a strong UN authority to enforce cooperation. The focus is on the so-called ambition mechanism in the Agreement. Conference President Fabius coined that term to include the provisions for a longterm direction of travel, building expectations of progressive ratcheting up of national climate efforts and tracking global progress.

Norway was deeply involved in the Paris end-game negotiations over these issues, following a request from the French Presidency. Fabius asked about a dozen of his ministerial colleagues to help facilitate the negotiation of some key political issues in the final high-level week of the Paris meeting. Typically, a pair of ministers, one from a developed country and one from a developing country, would co-chair such negotiations. One such pair was Norway's then Minister of Climate and Environment, Tine Sundtoft, and Saint Lucia's Minister for Sustainable Development and Energy, James Fletcher. They both had high credibility after participating in a large number of ministerial meetings leading up to Paris.

The purpose of the Paris Agreement is to increase individual and global efforts on three fronts simultaneously: to mitigate emissions, to adapt to adverse effects of climate change, and to mobilize finance and support for the necessary transformation. In this article, the focus is on mitigation.

Section 2 looks into the issue of participation. I argue that the principle of 'self-determination' helped attract wider participation. Section 3 discusses the implications of this principle for the possibility of enhancing collective climate efforts. Section 4 provides a more detailed account of how the so-called ambition mechanism was built into the Agreement, drawing on my own involvement in the negotiations in Paris, Section 5 discusses how effective conference diplomacy can significantly influence negotiation outcomes. The intense diplomatic engagement prior to and during the Paris Conference is highlighted. I argue that the French Presidency helped secure an ambitious outcome. Backchannel talks and informal coalitions were also instrumental in this regard. Finally, section 6 concludes.

\section{Attracting Participation through Self-Determination}

The main obstacle to universal participation in climate change agreements is widely seen to be the bifurcated nature of obligations for parties.
The Convention and follow-up decisions place much stronger obligations on industrialized countries to reduce greenhouse gas emissions. It has proven impossible to update the annexes that group countries by differentiated obligations, despite that both economic capabilities and emissions patterns have evolved dramatically over the last 25 years. $^{2}$ In the 1990s, emissions by traditional industrialized countries still represented more than half of global emissions. Since then, global emissions have grown by more than $40 \%$. OECD countries emit one third of the total, whereas developing countries account for the rest. The bifurcation and changing emission trends were at the core of previous negotiation rounds, such as the failed round in Copenhagen in 2009.

Hence, overcoming bifurcation was seen as a critical condition to secure universal participation in the Agreement. In fact, this obstacle was actually addressed well ahead of the Paris Conference. The key to attracting broad participation was to introduce the principle of 'self-determination'.

Kallbekken, Sælen and Underdal (2014) have discussed why it is difficult to reach agreement on what constitutes an equitable and ambitious contribution from individual parties. What is fair and ambitious to one party might be seen as unjust and inadequate to another.

A more flexible approach was widely seen as the viable way forward. In the lead-up to Paris, there was a growing understanding that the approach needed to shift from what Liebreich (2015) has coined 'top-down absolutism to bottom-up flexibility'. The jointly determined and legally binding emissions reduction targets in the Kyoto Protocol were replaced by bottom-up, nonbinding targets in Paris. The principle of selfdetermination was anchored already two years ahead of Paris at the Climate Conference in Warsaw in 2013, where parties agreed that countries' individual climate efforts under the new agreement should be prepared as 'nationally determined contributions' (UNFCCC, 2013).

This shift helped unleash an almost universal participation. By the opening of the Paris Conference, 186 of the 196 parties had presented their nationally determined contribution. This is about twice the number of parties that presented voluntary pledges in Copenhagen in 2009 and Cancun in 2010. Taking into account the different national circumstances of parties, the

2 The United Nations Framework Convention on Climate Change (UNFCCC) has two annexes. Annex 1 is the developed country Party list-the 1992 OECD countries, the European Commission, and economies in transition (Russia, Ukraine, Belarus, and some Eastern European states). Annex 2 is the donor country Party list, a subset of Annex 1 consisting of the then OECD countries and the European Commission. These annexes have not been updated since the Convention was adopted in 1992. 
bottom-up approach made it possible to arrive at more flexible and varied provisions than those in earlier agreements. The principle of self-determination contributed to attracting wider participation in the climate change agreement than ever before.

\section{Driving Ambition Over Time}

Climate mitigation involves a free-rider problem. As Hovi, Skodvin and Aakre (2013, p. 140) argue, 'actors have strong incentives to enjoy the benefits of other actors' mitigation efforts while not contributing to mitigation themselves. Climate mitigation will thus likely be provided only in suboptimal quantities'. Thus, while self-determination facilitates wider participation, it cannot guarantee sufficient collective action.

The trend of the contributions presented in Paris is that all parties pledge to do more than they have done before. Nevertheless, the individual plans do not add up to adequate mitigation efforts.

The UNFCCC $(2015,2016 b)$ found that aggregate global emissions levels resulting from what parties presented before the Paris Conference ${ }^{3}$ would overshoot the least-cost $2{ }^{\circ} \mathrm{C}$ scenario. The UNFCCC expects that the current contributions-if implemented as plannedwill slow down emissions growth by a third in the 20102030 period, compared to the 1990-2010 period.

If fully implemented, the pledges that governments made before the opening of the Paris Conference would limit warming to about $2.7{ }^{\circ} \mathrm{C}$ above preindustrial levels in 2100, according to the independent research consortium Climate Action Tracker (2015). ${ }^{4}$ This compares to $3.6{ }^{\circ} \mathrm{C}$ by 2100 , projected to result from current policies. Other studies have estimated higher temperature increases and it should be noted that aggregations are associated with uncertainty. ${ }^{5}$

The situation before the opening of the Paris Conference was that broad participation seemed to be within reach, while it was clear that the national targets put forward were inadequate. The main challenge for the end-game negotiations in Paris, therefore, was to find a way to build into the Agreement expectations that parties would significantly increase their climate efforts over time.

Mosa and Dovland (2015, p. 1) noted an emerging

\footnotetext{
${ }^{3}$ The updated UNFCCC synthesis report covers 189 countries, representing $95.7 \%$ of global emissions.

${ }^{4}$ Climate Action's Tracker Consortium consists of four research organizations: Climate Analysis, Ecofys, the New Climate Institute, and the Potsdam Institute for Climate Impact Research.

${ }^{5}$ Estimates are uncertain for a number of reasons: National pledges vary considerably in form and content, and many are difficult to quantify. It is not known whether pledges will be fully implemented or overachieved (several developing countries have stated in their pledges that they can do more with external support). Future climate efforts later in the century, after the current pledges, are hard to predict.
}

consensus before Paris among key negotiators concerning what was needed, that is, a 'hybrid agreement combining top-down and bottom-up elements with the aim of both broad participation and strong ambition' 6

Many delegations, including my own, saw the following elements as fundamental to a mechanism that could drive up ambitions over time: Firstly, securing a clear direction of travel in the Paris Agreement for a transition to low-emission societies. A long-term, global goal could provide such clarity. Secondly, capturing expectations that all parties need to enhance climate actions over time. Without progression, the long-term goal would not be credible. Thirdly, assurances that parties will actually do what they have pledged. Good reporting systems on progress towards meeting collective goals ${ }^{7}$ are essential to provide credibility to the long-term goal and to ensure transparency.

This set of issues is referred to as the 'ambition mechanism' of the Paris Agreement.

\section{The Ambition Mechanism in the Paris Agreement}

Norway and Saint Lucia's roles as deal brokers on the ambition mechanism in Paris proved to be as demanding as we had expected. If taken at face value, the negotiation positions revealed that there was no common ground between the 'must haves' of some countries and the 'red lines' of others. In the end, consensus was reached through several late-stage night sessions, closed for all but country representatives. Closed night sessions are less crowded-only those parties with the keenest interest participate. Building consensus first among a few, representative participants before reporting to the full group can be an effective dealmaking strategy. Willingness to compromise often increases as the deadline nears, as no party wants to be blamed for a failure.

\subsection{The Temperature Goal}

The Paris Agreement entails a sharpened long-term direction of travel than previous agreements do. In Copenhagen in 2009, parties agreed to limit global warming to $2{ }^{\circ} \mathrm{C}$ above pre-industrial levels. This goal is also reflected in the nonbinding Cancun Agreement (2010). In Paris, the goal was sharpened to keeping the increase in global average temperature to well below 2 ${ }^{\circ} \mathrm{C}$, while pursuing efforts to further limit the temperature increase to $1.5^{\circ} \mathrm{C}$.

The question of how to reflect the temperature goal proved perhaps the most difficult single issue that

\footnotetext{
6 Mosa and Dovland co-chaired an informal dialogue'Towards 2015'-with key negotiators from more than 20 countries. I write more on this dialogue in Section 5.

7 Transparency and reporting on individual targets are also important, but was not covered by the set of issues faciliated by Norway and Saint Lucia.
} 
Norway and Saint Lucia facilitated. Two negotiating groups, the alliance of small island states and of the least developed countries, had halting global warming at $1.5^{\circ} \mathrm{C}$ as their top demand (Ousman Jarju, 2016). For the low-lying islands, rapid reduction of global emissions is a matter of survival. However, both developed and developing countries voiced strong opposition to including a reference to $1.5{ }^{\circ} \mathrm{C}$. Some of the oilproducing developing countries were particularly hardline, as they perceived a more ambitious temperature goal as detrimental to their main export industry. The compromise came as part of an agreement on a separate issue, the treatment of loss and damage resulting from the adverse effects of climate change. The United States and other OECD countries agreed to $1.5^{\circ} \mathrm{C}$ as an aspirational goal in return for an explicit reference that provisions on loss and damage should not constitute any new liability or right to compensation.

Paris represents an advance over previous agreements also because the temperature goal is operationalized. Parties aim to reach global peaking as soon as possible and undertake rapid reductions thereafter. The aim is to achieve climate neutrality ${ }^{8}$ in the second half of this century. ${ }^{9}$

Many parties argued in favour of a clearer timebound climate neutrality target. Some wanted both a short-term target year for global peaking and a longterm target year for climate neutrality. They argued that it would be beneficial to agree on definite target years, as such agreement would facilitate the tracking of progress towards achieving the objectives of an agreement. However, ultimately parties did not feel comfortable about setting a short-term target year for global peaking for two reasons: because the scientific basis was unclear and because the question of how to deal with the understanding that developing countries would peak later was difficult to resolve. Similar concerns hindered agreement on a definite target year for climate neutrality.

It was nevertheless possible to agree on a stronger long-term goal than previously. Both the sharpened temperature goal and its operationalization in the Paris Agreement provide a clearer direction of travel.

\subsection{Enhancing Climate Action over Time}

An ambitious temperature goal is a necessary, but not sufficient condition to spur ambition. As noted, the

\footnotetext{
8 Defined in the Agreement as 'a balance between anthropogenic greenhouse gas emissions by source and removal by sinks'.

${ }_{9}^{9}$ Assurances are provided to developing countries. In particular, it is acknowledged that peaking will take longer for developing countries and that the efforts should be undertaken on the basis of equity and in the context of sustainable development and efforts to eradicate poverty.
}

first-round national pledges presented before Paris are inadequate to keep the temperature increase well below $2{ }^{\circ} \mathrm{C}$. To become more credible, the regime should encourage progressively more ambitious climate action over time.

The Paris Agreement delivers to some degree on that expectation. The Agreement states that successive rounds of national pledges will represent a progression beyond the current efforts. Furthermore, it also states that each party's pledge will 'reflect its highest possible ambition'. An update of self-determined climate pledges should take place every five years, starting in 2020.

From the outset, opposition was widespread against both of these elements. The principle of progression beyond current efforts was first agreed at the UN Climate Conference in Lima in 2014 (UNFCCC, 2014). It was seen as a necessary assurance to balance the principle of self-determined contributions. However, several parties were sceptical that this progression principle would apply also for future rounds of national pledges, perceiving that as too much interference in future national sovereign decisions. Others voiced concerns about 'gaming', that is, they feared that governments would present a low pledge because they would be expected to increase their efforts every five years. Ahead of the Paris Conference, only two countries, Switzerland and Norway, were clearly in favour of including a 'highest possible ambition' principle. They saw this principle as essential in a regime with selfdetermined climate targets.

Eventually, the principle provides assurances to all negotiation groups. Developing countries perceived it as a reassurance that countries with the highest capabilities should continue to take the lead. Many developed countries welcomed it because it builds into the Agreement the expectation that all parties will undertake their best efforts. This group includes a number of countries that so far had no quantitative mitigation pledge under the UNFCCC.

The principle was ultimately accepted. Its inclusion provides a dynamic element in the Paris Agreement. It encapsulates expectations that parties will regularly increase their national climate actions, according to their best efforts.

\subsection{Taking Stock of Collective Progress}

Tracking global progress is the third element of the ambition mechanism. Transparency is essential to build trust and confidence in a multilateral regime. In an effective regime, one of the functions of a transparency system is to promote implementation and to monitor progress towards the objectives.

While Norway and Saint Lucia did not facilitate the negotiations on the transparency of individual efforts, they were in charge of the negotiations on tracking collective progress. 
In Paris, it was agreed to periodically take global stock of the implementation of the Agreement. These stocktakes will assess the collective progress towards achieving the Agreement's purpose and long-term goals. ${ }^{10}$ Furthermore, it was agreed that the outcome of the global stocktakes shall inform parties in updating and enhancing their subsequent national pledges. The global stocktakes will occur two years ahead of each new national pledging cycle. Thereby, the latest available data will be available when formulating new, individual climate action. The first report on global emissions will be presented in 2018, followed by global stocktakes every five years.

The system of regular global stocktakes was a controversial one in the negotiations. Major developing countries were sceptical; they perceived this system as infringing on their national sovereignty. It was possible to reach agreement only by emphasizing the collective nature of the stocktakes. The adequacy of countries' individual climate efforts will not be assessed.

The inherent conflict between participation and ambition is therefore not fully resolved in the Paris Agreement. Nevertheless, the conflict is addressed more successfully than in previous agreements. Ultimately, there was no direct trade off: Wide participation was secured without weakening expectations about future enhancement of national climate efforts.

Taken together, the elements of the ambition mechanism could become a vehicle to progressively drive ambitions. If implemented, enhanced climate action will follow from the obligation of regular ratcheting up of self-determined efforts. The principles of progression and highest possible ambition anchor clear expectations. The regular stocktakes of collective efforts will further guide future individual actions. Thereby, the ambition mechanism offers an opportunity for a 'virtuous cycle' for progression over time.

The inherent free-riding problem is not resolved in the Paris Agreement: There is no guarantee that parties will actually undertake what they commit to, that is to increase their efforts significantly over time. However, the Paris Agreement makes it is harder for the free rider to carry on unnoticed. In the absence of a strong UN authority to enforce cooperation, the ambition mechanism will be a political norm. The ambition mechanism provides a yardstick to measure performance and progress (or lack thereof), including a commonly agreed benchmark for informal 'blaming and shaming'. Nevertheless, in any international regime that promotes voluntary, cooperative behaviour, the future effectiveness in largely determined by political will.

10 The global stocktakes will also include an assessment of progress towards the adaptation and climate finance objectives, not discussed here.

\section{Conference Diplomacy: Negotiating the Climate Deal}

Climate diplomacy rose to unprecedented levels in the two years prior to the Paris Conference. There was a plethora of diplomatic initiatives. France launched a number of events, individually and together with Peru, the preceding Presidency of UN Climate Conference. The United States, Germany, the European Union, and many others held high-level workshops and dialogues. The USChina presidential summits in 2014 and 2015, which led to a crucially important agreement between the two countries (White House, 2015), were but two of many bilateral meetings on climate change. Several countries instructed their embassies to file weekly reports on climate-related developments in their hosts' countries.

Such climate diplomacy efforts were geared towards exploring possible compromises prior to the final negotiations rounds. Back-channel negotiations outside the formal UN setting were critical to understand the concerns of others and to construct elements of comprehensive consensus solutions.

Such initiatives also included unofficial dialogues providing a more secure environment for frank, offthe-record exchanges. This environment resembles socalled Track 2 Diplomacy, which is 'a process designed to assist official leaders...by exploring possible solutions out of the public view and without the requirements of formal negotiations or bargaining for an advantage' (Montville, 2006, p. 16). Gambia's minister of the environment, Pa Ousman Jarju (2016), has highlighted the contributions of one such unofficial initiative, the Towards 2015 International Climate Dialogue. This initiative assembled key negotiators from more than 20 countries in an 18-month sequence of meetings. Diringer (2015) has analysed how this dialogue reached broad consensus on many of the concepts that later were included in the Paris Agreement.

\subsection{The Role of the French Presidency}

The timing of the Conference was opportune for a successful result. There was a growing appreciation about the urgency. A 'now or never' sensation increased political will. In addition, reports such as the ones from the Global Commission on Economy and Climate underscored the opportunities for green transformation (New Climate Economy, 2014, 2015).

The French Presidency cleverly enhanced these favourable trends at the Paris Conference. Together with Peru, they launched a high level 'action agenda' where solutions were demonstrated and new partnerships were developed. In addition, France invited heads of states and governments to the opening of the Conference. At previous conferences, ministers had come only towards the end. Building political momentum at the opening of the Conference was a novel idea, and one 
that proved successful. ${ }^{11}$ It resulted in an unprecedented manifestation of political will.

The French Presidency also prepared parties well before the Conference. A series of high-level meetings were organized on specific themes. The Presidency introduced a new procedure at these pre-meetings. Ministers would only be allowed short general remarks in a plenary setting (drawing mostly from written statements). Then, ministers were divided into break-out groups and asked to answer pointed questions which had not been circulated in advance. This setting spurred more focused discussions and true dialogue. This innovative organization of pre-meetings contributed to better understanding of parties' concerns and explored bridging proposals. In many ways, these premeetings mirrored the end-game negotiations and paved the way for the compromises made at the Paris Conference.

At the Conference itself, President Fabius and his team shepherded the process inclusively and transparently. In Paris, before presenting the final text for adoption, the Presidency had extensive consultations with major countries and all negotiating groups. I witnessed this impressive conference diplomacy first-hand as I had the privilege to work on some last-minute textual solutions together with members of the French team.

Another factor was that the Presidency managed to transcend any perceptions that France was firmly in the EU camp. The French team convincingly portrayed themselves as open to all parties, understanding the concerns of all. French politicians and officials undertook impressive diplomatic efforts leading up to Paris. France had strategic dialogues with all critical countries well ahead of the Conference. Members of the French government crisscrossed the world. This huge and critical diplomatic effort helped lay the foundation for an outcome that exceeded the expectations of many observers and negotiators. ${ }^{12}$

In addition, the Presidency consistently communicated a clear sense of direction. They showed clear leadership. It was clear to all that France did not want merely an agreement with universal participation, but a comprehensive and ambitious one. At one point in their roles as facilitators, Norway and Saint Lucia had to report to the Presidency that if a consensus text on the temperature goal were to be presented at that time, the high-ambition option would have to be taken off the negotiating table. Conference President Fabius strongly advised us to keep the high-end options in the

11 In Copenhagen in 2009, heads of states and governments arrived towards the end of the conference, complicating the endgame negotiations.

12 The author participated in the "Predicting Paris: Multi-Method Approaches to Forecast the Outcomes of Global Climate Negotiations" study discussed by Sprinz et al. (2016) in this volume. My own predictions were on the low side of the outcome. revised text. Behind the scenes, France worked successfully to get the strongest opponents on board, among them three G20 countries. Whenever the limited leverage of small-power facilitators such as Norway and Saint Lucia became obvious, France and other major powers employed high-level diplomacy to secure a comprehensive and ambitious deal.

\subsection{A New Force in the Negotiations: The High Ambition Coalition}

Several back-channel groups across the negotiation blocks underpinned the leadership of the French Presidency. The most influential turned out to be a group very few had heard of before Paris. It became known as the High Ambition Coalition. ${ }^{13}$ In a situation where region and development levels define the formal negotiating blocks, this group was inclusive yet remained small for most of the Conference. The core group consisted of about a dozen countries. Apart from the European Union, small countries originally made up the group. ${ }^{14}$

The High-Ambition Coalition became a game changer through a remarkable snowball effect in Paris. At a press conference two days before the end of the Conference, the United States for the first time emerged publicly as part of the group, and was followed by Brazil the following day. Before the end of the Conference, over a hundred countries supported the messages of this loose coalition calling for a comprehensive and strong agreement (Climate Change News, 2015).

Tony de Brum, Foreign Minister of the Republic of the Marshall Islands at the time, masterfully led the High Ambition Coalition. In the lead-up to the Paris Climate Conference, he called meetings in the core ministerial group four times, on the margins of other climate-related meetings. ${ }^{15}$ The Marshall Islands was an ideal champion, with an exceptionally experienced minister and resourceful negotiation team. The country is also a 'moral superpower'. Consisting of low-lying coral atolls rising only a few feet above sea level, it is more vulnerable to the adverse effects of climate change than most other countries are.

The European Commission (EC) and Norway played key roles in building this back-channel diplomacy. Commissioner Arias Canete has called it 'the masterplan

\footnotetext{
13 Former US Climate Envoy Todd Stern came up with this name in the first full meeting of the group the United States attended, a working dinner in Paris, 6 December 2015.

${ }^{14}$ The last ministerial meeting Norway and the EU Commission organised, held on 17 May 2015 in Berlin, had representatives from 13 parties: Angola, the EU Commission, Gambia, Germany, Grenada, the Republic of the Marshall Islands, Mexico, Norway, Peru, Saint Lucia, Switzerland, and the United Kingdom.

15 The 2015 progressive ministerial meetings took place as follows: 17 May in Berlin, 20 July in Paris, 28 September in New York, and 8 November in Paris. There were also several meetings during the Paris Conference itself.
} 
of Europe and its allies conceived over the year' and argues that the first meeting of the group was held on 17 May 2015 (EC, 2015, p. 1). In fact, the basis of the coalition was established already during the Climate Conference in Durban in 2011. The group was the brainchild of Connie Hedegaard (personal communication, 21 February 2016), the energetic former EU Commissioner for Climate Action. She saw the need to bring together ministers from ambitious countries. Erik Solheim (personal communication, 23 February 2016), then Norway's Minister of the Environment, was also enthusiastic about the idea of bringing together ministers with similar mindsets across different negotiation groups to help find ambitious compromises. The EU Commission and Norway continued to convene ministers from 'progressive countries' from 2011 onwards. They typically funded and co-chaired such informal ministerial meetings twice a year. The coalition continued despite changes of ministers. Norway's minister Tine Sundtoft co-chaired several meetings in this format, both with Connie Hedegaard and with her successor, Miguel Arias Canete. Norway and the EU Commission invited the Marshall Islands to co-chair a meeting in May 2015 in Berlin, ${ }^{16}$ after which Foreign Minister Tony de Brum took over as convener.

Outside the limelight of official meetings, the coalition had met at both the ministerial and the lead negotiator levels throughout the year. In the lead-up to Paris, the group discussed what strategies to pursue to get a strong agreement. Members of the group tried to create mutual trust and to find common ground. They worked on concrete language solutions on some of the politically most contested issues. Positions were aligned, where possible. In the negotiation rooms, delegates from the coalition pushed for ambitious outcomes. They echoed and supported each other, even before other parties realized that views had been aligned through back-channel diplomacy over the course of the year. The outcome regarding the ambition mechanism eventually was very close to the demands by the coalition: 'A firm recognition of the below 1.5 degrees temperature goal; a collective mitigation pathway entailing deep cuts by mid-Century and five-yearly common political moments to revisit mitigation targets, informed by five-yearly global stocktakes' (Bialek, 2015).

The informal coalition was instrumental in keeping the more ambitious options on the table in the final round of negotiations. The group created 'a political space' for the French Presidency to ensure ambition in the final draft Agreement. Some of the major developing countries had long argued in favour of a limited agreement. Such an agreement would have few details and very little guidance on how to enhance efforts in

16 Mary Robinson, UN Special Envoy for Climate Change at the time, advised us to include a developing country in the leadership of the progressive ministerial meetings. the future. These developing countries could no longer hide behind poorer developing countries with little capacity, because many of the most vulnerable countries had become vocal champions of high ambition.

The High Ambition Coalition contributed to the making of a comprehensive and strong agreement. In the closing days in Paris, the narrative was changing: The divide was not so much between North and South, but rather between those who wanted a strong and ambitious deal and those who did not. The coalition helped bridge the unhelpful and rigid bifurcation between developed and developing countries. In the areas facilitated by Norway and Saint Lucia, ${ }^{17}$ this backchannel dialogue clearly helped tip the balance and influenced the final outcome.

\section{Conclusion}

The Paris Agreement represents the culmination of years of climate diplomacy. From my vantage point as Chief Negotiator of Norway, I am convinced that the comprehensive outcome in Paris may in part be attributed to the unpreceded diplomatic efforts during and prior to the Paris Conference. Conference diplomacy impacted negotiation outcomes.

In this article, the importance of inclusive leadership is emphasized. I argue that the French Presidency combined a transparent negotiations process with a clear sense of direction that helped navigate the Paris Agreement into the more ambitious end of the spectrum of possible results. An illustration is offered where the Presidency refused a middle-ground compromise and instead pursued bilateral high-level diplomacy to secure the high-ambition options.

I also discuss the important role of back-channel negotiations. Effective conference diplomacy must cut across formal negotiation blocks and build bridges. I particularly look at the emergence and impact of one informal group, the High Ambition Coalition. Its formation softened the rigid divide between North and South and helped forge compromises.

The Paris Agreement has mobilized almost universal participation through nationally determined contributions. Self-determination is at the heart of many provisions. This shift from previous top-down approaches has spurred participation.

In addition, the Agreement anchors a clearer direction of travel than before. Provisions are built into the Agreement to enhance national climate efforts progressively over time. Thereby, the inherent conflict between broad participation and ambition in climate change negotiations has been resolved in the Paris Agreement more successfully than in previous agreements.

\footnotetext{
17 Worth noting is that the Presidency chose ministers in this core group of the coalition to facilitate the ambition mechanism.
} 
The first round of self-determined climate action does not add up to what is needed to meet global targets. However, the Paris outcome cannot be judged solely by looking at the emissions reduction targets that were put forward prior to the Paris Conference. The Paris Agreement is a hybrid between bottom-up flexibility and top-down guidance. One of the keys to bringing both developed and developing countries into legally bound provisions is the self-determined nature of several provisions, combined with a mechanism to regularly ratchet up efforts. Given future political will, that combination could become a vehicle to increase climate ambitions significantly over time.

\section{Acknowledgements}

I appreciate comments on an early draft from Professor Dag Harald Claes, Executive Vice President Elliot Diringer, Director Steffen Kallbekken, and my colleagues in the Norwegian negotiation team, Georg Børsting, Henrik Eriksen and Gard Lindseth. The editors of this thematic issue, Professor Tora Skodvin and Professor Jon Hovi, have been particularly helpful. I also benefited from useful comments from three anonymous reviewers. I am of course indebted to the French Presidency for their request to and confidence in Norway to help facilitate the ambition mechanism of the Paris Agreement. My own insights from conference diplomacy would be less rich without this experience.

\section{Conflict of Interests}

The author declares no conflict of interests.

\section{References}

Bialek, D. (2015). Some joint messaging and "points of convergence." Unpublished email to High Ambition Coalition contact points, 9 December 2015.

Climate Action Tracker. (2015). $2.7{ }^{\circ} \mathrm{C}$ is not enoughWe can get lower. Climate Action Tracker Update Paper, 8 December 2015.

Climate Change News. (2015). Brazil backs "high ambition coalition" to break Paris deadlock. Climate Change News. Retrieved from http://www.climate changenews.com/2015/12/11/brazil-backs-highambition-coalition-to-break-paris-deadlock

Diringer, E. (2015). How we helped on the road to Paris. Center for Climate and Energy Solutions. Retrieved from http://www.c2es.org/blog/diringere/how-wehelped-road-paris

European Commission. (2015). Commissioner for Climate Action and Energy, Miguel Arias Canete: Historic climate deal in Paris. European Commission Press Release, 14 December 2015. Retrieved from http://europa.eu/rapid/press-release_SPEECH-156320_en.htm
Hovi, J., Skodvin, T., \& Aakre, S. (2013). Can climate change negotiations succeed? Politics and Governance 2013, 1(2), 138-150.

Kallbekken, S., Sælen, H., \& Underdal, A. (2014). Equity and spectrum of commitments in the 2015 agreement (Nordic Council of Ministers Report 2014: 519). Denmark: Nordic Council of Ministers.

Liebreich, M. (2015). We'll always have Paris. Bloomberg New Energy Finance.

Montville, J. (2006). Track two diplomacy: The work of healing history. Whitehead Journal of Diplomacy and International Relations, 17(2), 15-25.

Mosa, V., \& Dovland, H. (2015). Vision of Paris: Building an effective climate agreement. Center for Climate and Energy Solutions. Retrieved from http://www. c2es.org/docUploads/vision-for-paris-07-2015.pdf

New Climate Economy. (2014). Better growth with better climate. Charting a new path for low-carbon growth and a safer climate. Retrieved from http:// 2014.newclimateeconomy.report

New Climate Economy. (2015). Seizing the global opportunity. Partnerships for better growth and a better climate. Retrieved from http://2015.newclimate economy.report

Ousman Jarju, P. (2016). A diplomatic approach to raising climate ambition. Climate and Development Knowledge Network. Retrieved from http://cdkn.org/ 2016/02/opinion-a-diplomatic-approach-to-raisingclimate-ambition-pa-ousman-jarju/?loclang=en_gb

Sprinz, D., De Mesquita, B., Kallbekken, S., Stokman, F., Sælen, H., \& Thomson, R. (2016). Predicting Paris: Multi-method approaches to forecast the outcomes of global climate negotiations. Politics and Governance, 4(3), 172-187.

United Nations Framework Convention on Climate Change. (2013). Decision 1/CP.19 adopted at COP 19.

United Nations Framework Convention on Climate Change. (2014). Decision 1/CP.20 adopted at COP 20.

United Nations Framework Convention on Climate Change. (2015). Synthesis report on the aggregate effect of the INDCs (FCCC/CP/201/5/7).

United Nations Framework Convention on Climate Change. (2016a). Laurent Fabius sums up Paris Agreement strengths and key objectives for 2016. Remarks to COP21/CMP11 Bureau Meeting. UNFCCC Newsroom. Retrieved from http://newsroom.unfccc. int/unfccc-newsroom/laurent-fabius-reflections-onthe-paris-conference-and-implications-for-2016

United Nations Framework Convention on Climate Change. (2016b). Updated synthesis report on the aggregate effect of the INDCs (FCCC/CP/2016/2).

White House (2015). US-China joint Presidential statement on climate change. White House Press Release, 25 September 2015. Retrieved from https://www. whitehouse.gov/the-press-office/2015/09/25/uschina-joint-presidential-statement-climate-change 


\section{About the Author}

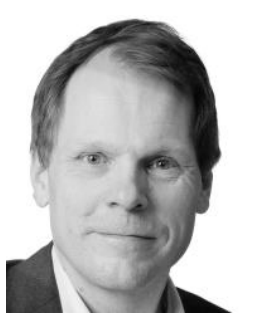

Aslak Brun is Norway's Chief Climate Negotiator with the Ministry of Climate and Environment. A career diplomat, his previous positions include Director of the Section for Climate, Global Health and Sustainable Development in the Ministry of Foreign Affairs. He is a political scientist from the University of Oslo. 